\title{
Implications of Funding Practices on Adequacy of Physical Facilities and Learners' Academic Achievement in Public Secondary Schools
}

\author{
Caroline Nabwoba Simiyu* Elizabeth Abenga Aggrey Mukasa Simiyu \\ Department of Curriculum and Instructional Technology \\ Masinde Muliro University of Science and Technology, \\ P.O. Box 190-50100, Kakamega. Kenya
}

\begin{abstract}
Education is a human activity that fashions and models man for the society. This is only possible with quality education. Funding has implications on the quality of education of which schools physical facilities are an integral part. The study employed survey design on a target population of 252 public secondary schools from which 36 made up the study population. The principals, heads of academic departments and school bursars from the 36 schools in addition to the County Director of Education were respondents. The study found out that funding practices had an association with the provision of adequate physical facilities. It also established that utilization of the physical facilities had an association with learners' academic achievement. However allocation of funds had no direct association with learners' academic achievement. The study concluded that funding practices have an indirect association with learners' academic achievement. The implication of this being that funding practices have to ensure provision of adequate physical facilities which have to be utilised in the teaching learning process in order to realise positive learners' academic achievement.
\end{abstract}

Keywords: Adequacy physical facilities, Funding Practices, Learners' academic achievement, Utilisation of physical facilities

DOI: $10.7176 / \mathrm{JEP} / 11-23-05$

Publication date:August $31^{\text {st }} 2020$

\section{Introduction}

The aspect of quality education has been the guiding principle of the Kenyan Government. Government participation in the funding of education is aimed at increasing the quality of education. According to UNICEF (2000), some of the indicators of quality education include performance which could be in terms of test scores posted by students and an environment that provides adequate learning resources and facilities. Funding is a key element among educational resources because they determine the acquisition of other resources such as physical resources, human resources and instructional materials in a school. Schools make a difference when their economic resources are allocated to create a conducive social environment (Ayoti, Koteng \& Odhiambo, 2016; Wenglinsky, 1997). Studies conducted in several countries have shown that resource allocation affects students' academic achievement in public schools, (Lumuli, 2009). World Bank (2012) concurs that depending on the context and under the right conditions, increasing inputs that are in scarce supply can lead to a high marginal return on the learning process.

Research has shown that funding has a positive impact on academic performance (Sherlock, 2011). These findings were validated by a later research conducted in Mumias region in Kenya in 2014 by Sisungo, Kaberia and Buhere which showed that there is a significant positive correlation between school level of funding and performance in KCSE examinations. Provision of good quality education requires adequate physical facilities such as classrooms, laboratories and libraries which are acquired through the available funds in schools. This makes funding a key aspect in the provision of education, (Mbati, 2004). A study conducted in public secondary schools in the former Bungoma South District in Kenya by Bakari, Likoko and Ndinyo in 2012, revealed that schools with adequate physical facilities had a superior academic advantage over those with less physical facilities.

According to Lucas and Mbiti (2014), National schools which admit top performing primary school candidates across the nation have better facilities as compared with provincial and district schools. Ndiku and Muhavi (2013) argues that the old well established schools have relatively higher levels of efficiency than the upcoming day secondary schools and district schools because they have much of the required infrastructure.

Schools in Kenya are under pressure to improve academic performance (MOEST, 2005). According to Lips et al (2008), many people are of the view that spending more on education correspondents to academic achievement. World Bank report on education recommends for the investment in outputs that most effectively affect student learning achievement (World Bank, 2008). Julia Gillards who is the chair the Global Partnership for education affirms that if spending on education was efficient, then the world it would mitigate on low learning outcomes (World Bank, 2018).

A research on the relationship between funding and academic achievement as reported in the Asian Journal 
of Educational Research (2010) showed that schools with a higher revenue base performed better than those whose income was low. World Bank (2018) asserts that, as much as educational resources are necessary, they may not be sufficient to produce higher levels of student learning especially in excessive large classes of more than 60 students.

\subsection{Funding and availability of physical facilities}

Condron and Roscigno (2003), argue that spending on school buildings may also shape achievements since better physical facilities create a more conducive environment for learning. Munda and Odebero (2014), argues that the attainment of education related millennium goals in Kenya are mainly dependent on the availability and the correct use of funds to acquire supportive inputs for the education process.

Wamulla (2013) from his studies states that the availability of physical and teaching facilities have a positive influence on learners' academic performance. There is actually a general belief that the condition of school's learning environment, especially infrastructure has an important impact on students' academic performance and effectiveness. The facilities that are needed to facilitate effective learning in an educational institution include adequate power and water supply, adequate classrooms, libraries, laboratories as well as furniture and sporting equipment among others. The quality of infrastructure has strong influence on the academic standard which is an index of quality assurance in the school (Sunday, 2012). Unavailability of critical facilities such us laboratories may affect delivery of science oriented subjects since this is where the learners practice the taught concepts. Laboratories therefore need to be installed and equipped with required apparatus and chemicals. In the case of the library, it needs to be equipped with sufficient books. School facilities such as buildings that are used for academic and non-academic purpose, equipment, classroom facilities, furniture, toilets, ICT, library and laboratory materials and others play a pivotal role in the teaching and learning process (Hailu \& Biyabeyen, 2014). According to Schneider (2002) school facilities have a direct effect on teaching and learning and as such unattractive physical structures could de-motivate learners academically. Generally, a favourable school climate gives room for students to work hard and enhance their academic achievement (Sunday, 2012). Redan, Marlina and Betaubun (2014) in their research findings state that unavailability of adequate school physical facilities and infrastructures directly influenced the teaching learning process in the classrooms and, in turn, affected the learners' academic achievement in schools.

A research conducted in Makueni county Kenya showed a strong correlation between availability of learning resources and performance (Kimeu, Tanui and Ronoh, 2015). A related research which had been conducted earlier in the former Rift Valley province had also shown that schools equipped with adequate and relevant resources performed better in National examinations than schools with inadequate learning resources (Kurgat, 2014). According to the Organization for Economic Cooperation and Development (OECD), resource shortages hinder instruction and therefore lower student performance. Facilities such as effective school Libraries provide additional reading opportunities for students which in turn improve reading skills, comprehension, writing and clarity of expression hence support student performance in all other curriculum subjects. This research therefore explored into the issue of allocation of funds in relation to availability of physical resources and its impact on learner academic achievement in secondary schools Bungoma County, Kenya.

\section{Methodology}

The study employed the descriptive survey design. The target population consisted of 252 public secondary schools of which 36 constituted the study population. Stratified sampling was employed to ensure representation of all sub-counties in the county and all categories of public secondary schools. Of the selected schools, the principals, bursars and heads of academic departments (HoDs) were respondents in this study. The County Director of Education was also a respondent in this study. The study employed questionnaires, structured interview schedules and document analysis as instruments of data collection. The SPSS Package was used in the analysis of quantitative data. Descriptive statistics using mean and standard deviation were used to organise, analyse, present and describe the data from respondents using tables and figures, while inferential statistics were used to make generalisation based on findings from the sampled schools. A Pearson correlation was used to determine the possibility of existence of any relationship between variables of the study.

\subsection{Results}

\subsection{Funding practices and adequate provision of physical facilities}

The study sought to evaluate the effects of funding practices on the adequacy of physical infrastructure in secondary schools in Bungoma County. The study did this by looking at the adequacy of physical resources that support education. School physical facilities are fundamental for better learning environment and achievements, hence the outcome of the students (Saeed \& Wain, 2011). Other studies have shown that availability of the physical facilities like drinking water, technology, toilets, furniture, playgrounds, and libraries have a significant positive role on the performance of the students and their academic achievement (Bijaya \& Maharjan, 2015). 
Respondents were asked to indicate the extent to which they agreed with a list of statements concerning adequacy of provision of physical facilities within the schools on a five points scale with 1 being the lowest corresponding to strongly disagree, 3 neutral and 5 the highest corresponding to strongly agree after coding. The physical facilities listed were furniture in the staffroom/offices, furniture in the classrooms, library facilities, science laboratory facilities, home science / agriculture room facilities, latrines / toilets, offices allocated to departments, dining hall facilities, play fields, availability and reliability of clean water, and availability and reliability of power.

The comparison of the degree to which respondents agreed to the adequacy of the physical facilities was as presented in figure 1 .

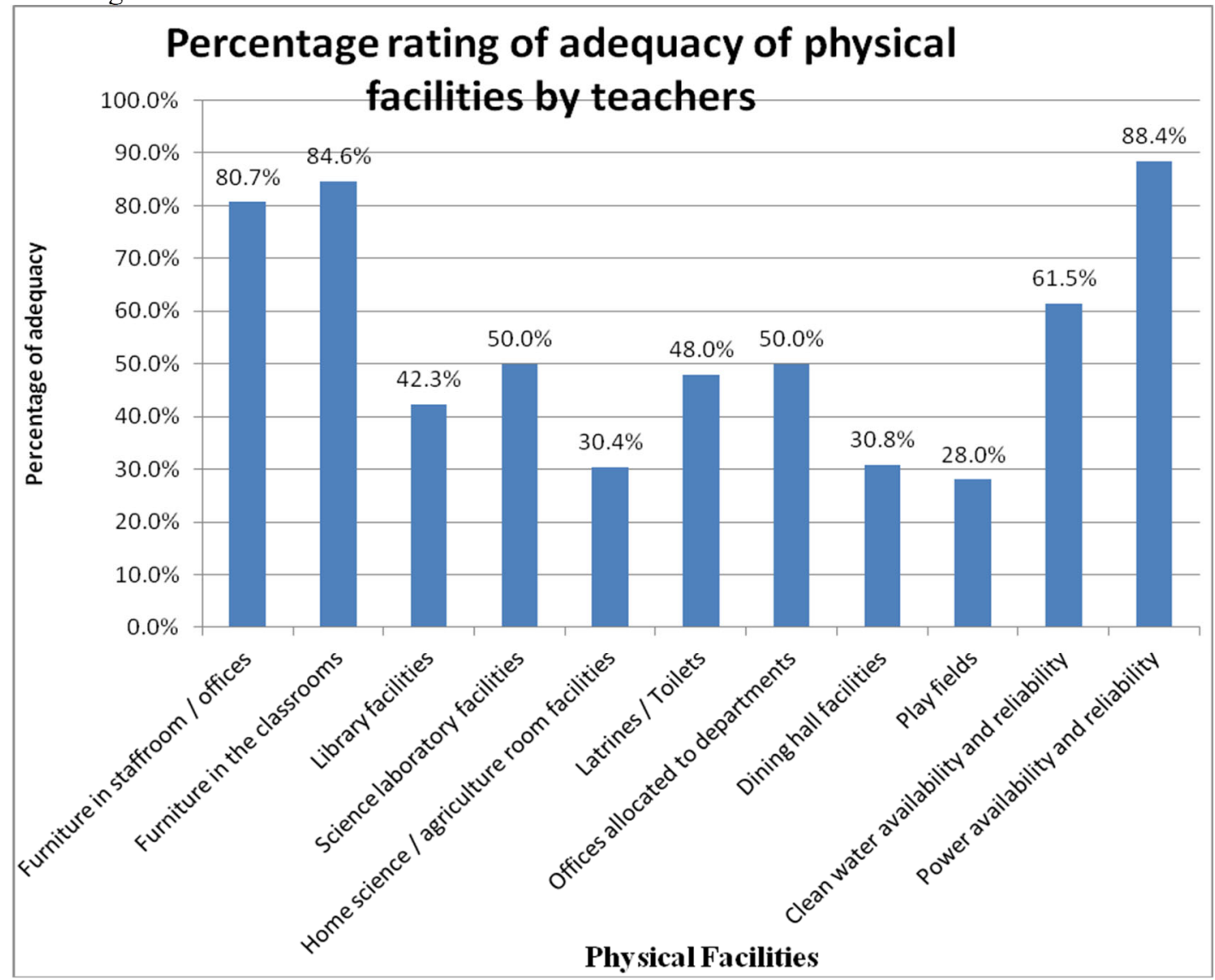

Figure 1: Level of physical facilities provision

Considering $60 \%$ as the pass level for adequate provision, it would be observed from figure 1 that power supply $(88.4 \%)$, furniture in the classrooms $(84.6 \%)$, furniture in the staffroom $(80.7 \%)$ and clean water supply $(61.5 \%)$ meet the threshold. The rest of the facilities were below threshold. However those facilities moderately provided for were inclusive of science laboratories and offices allocated to departments at $50 \%$, toilets / latrines $(48 \%)$ and library facilities $(42.3 \%)$. The play grounds $(28 \%)$, capacity and equipment for home science /Agriculture (30.4\%) and dining hall facilities (30.8\%) were the worst in terms of provision.

The summary of the level of provision of the physical facilities when ranked from the better provide for is summaries in table 1. 
Table 1: Ranking of adequacy of physical facilities

\begin{tabular}{|llc|}
\hline Serial & Physical facility and teaching learning resource & $\%$ of adequate response \\
\hline 1. & Power supply & $88.4 \%$ \\
\hline 2. & Furniture in classrooms & $84.6 \%$ \\
\hline 3. & Furniture in the staffroom/offices & $80.8 \%$ \\
\hline 4. & Clean water supply & $61.5 \%$ \\
\hline 5. & Books' and equipments' storage facilities & $57.7 \%$ \\
\hline 6. & science laboratory facilities & $50.0 \%$ \\
\hline 7. & Number of offices allocated to departments & $50.0 \%$ \\
\hline 8. & Number of latrines / toilets & $48.0 \%$ \\
\hline 9. & Library facilities & $42.3 \%$ \\
\hline 10. & Dining hall facilities & $30.8 \%$ \\
\hline 11. & Home science / Agriculture room facilities & $30.4 \%$ \\
\hline 12. & Play fields & $28.0 \%$ \\
\hline
\end{tabular}

From table 1, physical facilities on the overall were fairly provided for however it is observable that they were not equally provided for across the board. Such insufficient provision of the physical facilities leads to a strained learning environment and may easily affect educational service provision as students overstretch the physical facilities (Bizimana and Aluko, 2014).

An interview with the County Director of Education, Bungoma County revealed that the general status of schools infrastructure across the county was below average and there was need to sensitize stakeholders to understand where the county was and make improvement. Most of the principals interviewed indicated that there was an assumption by the government that schools have adequate infrastructure. Most schools prioritized the area of staffing instead of infrastructure. The school principals acknowledged that operational money was used to pay teachers instead of developing the infrastructure of the schools.

\subsection{Association between determinants of funds allocation and adequate provision of physical facilities}

Pearson Product Moment Correlation was applied on the findings to determine whether there was any association between the determinants of funds allocation and the provision of physical resource. The findings are presented in table 2. According to Asuoro, Sayago and Gonzalez (2006), Pearson Product Moment Correlation coefficients of 0.00 to 0.29 implies little if any association, 0.3 to 0.49 implies low association, 0.5 to 0.69 implies moderate association, 0.7 to 0.899 implies high association and 0.9 to 1.00 implies very high association. The association normally will have either a positive or negative direction as indicated by the sign on the coefficient value. Table 2: Correlation of determinants of funds allocation with adequacy of physical facilities

\begin{tabular}{|c|c|c|c|c|c|c|c|c|c|c|c|c|}
\hline Determinants of & inds allocation &  & 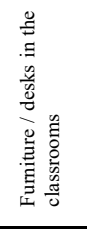 &  & 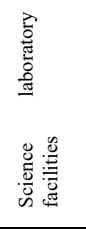 &  & 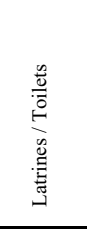 & 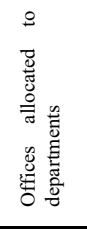 & 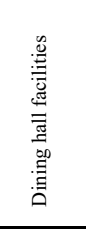 & $\begin{array}{l}\frac{n}{0} \\
\stackrel{0}{d} \\
\frac{\vec{a}}{a}\end{array}$ & 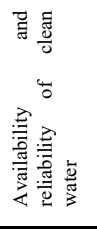 & 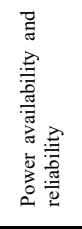 \\
\hline \multirow[t]{3}{*}{$\begin{array}{l}\text { School's } \\
\text { strategic plan }\end{array}$} & $\begin{array}{l}\text { Pearson } \\
\text { Correlation }\end{array}$ & $.557(* *)$ & $.273(* *)$ & $.413(* *)$ & $.575(* *)$ & $.667(* *)$ & $.737(* *)$ & $.719(* *)$ & $.557(* *)$ & $\left..639{ }^{* *}\right)$ & $.739(* *)$ & $.578(* *)$ \\
\hline & Sig. (2-tailed) & .000 & .000 & .000 & .000 & .000 & .000 & .000 & .000 & .000 & .000 & .000 \\
\hline & $\mathrm{N}$ & 182 & 182 & 182 & 182 & 161 & 175 & 182 & 182 & 175 & 182 & 182 \\
\hline \multirow[t]{3}{*}{$\begin{array}{l}\text { Departmental } \\
\text { budget }\end{array}$} & $\begin{array}{l}\text { Pearson } \\
\text { Correlation }\end{array}$ & $.554(* *)$ & $.208(* *)$ & $.530(* *)$ & $.716(* *)$ & $.733(* *)$ & $.777(* *)$ & $.853(* *)$ & $.601(* *)$ & $.680\left(^{* *}\right)$ & $.783(* *)$ & $.555(* *)$ \\
\hline & Sig. (2-tailed) & .000 & .005 & .000 & .000 & .000 & .000 & .000 & .000 & .000 & .000 & .000 \\
\hline & $\mathrm{N}$ & 182 & 182 & 182 & 182 & 161 & 175 & 182 & 182 & 175 & 182 & 182 \\
\hline \multirow[t]{3}{*}{$\begin{array}{l}\text { The school's } \\
\text { priorities }\end{array}$} & $\begin{array}{l}\text { Pearson } \\
\text { Correlation }\end{array}$ & $.332(* *)$ & $.192(*)$ & $.337(* *)$ & $.304(* *)$ & $.214(* *)$ & $.397(* *)$ & $.489(* *)$ & $.313(* *)$ & $.465\left(^{* *}\right)$ & $.498(* *)$ & $.348(* *)$ \\
\hline & Sig. (2-tailed) & .000 & .012 & .000 & .000 & .009 & .000 & .000 & .000 & .000 & .000 & .000 \\
\hline & $\mathrm{N}$ & 168 & 168 & 168 & 168 & 147 & 163 & 168 & 168 & 164 & 168 & 168 \\
\hline \multirow[t]{3}{*}{$\begin{array}{l}\text { The school's } \\
\text { characteristics }\end{array}$} & $\begin{array}{l}\text { Pearson } \\
\text { Correlation }\end{array}$ & $.513(* *)$ & $.283(* *)$ & $.503(* *)$ & $.636(* *)$ & $.619(* *)$ & $.675(* *)$ & $.812(* *)$ & $.483(* *)$ & $.660\left(^{* *}\right)$ & $.773(* *)$ & $.629(* *)$ \\
\hline & Sig. (2-tailed) & .000 & .000 & .000 & .000 & .000 & .000 & .000 & .000 & .000 & .000 & .000 \\
\hline & $\mathrm{N}$ & 182 & 182 & 182 & 182 & 161 & 175 & 182 & 182 & 175 & 182 & 182 \\
\hline \multirow[t]{3}{*}{$\begin{array}{l}\text { The type of } \\
\text { school }\end{array}$} & $\begin{array}{l}\text { Pearson } \\
\text { Correlation }\end{array}$ & $.634\left(^{* *}\right)$ & $.207(* *)$ & $.513(* *)$ & $.566(* *)$ & $.522(* *)$ & $\left..685{ }^{(* *}\right)$ & $.790(* *)$ & $.480(* *)$ & $.602(* *)$ & $.745(* *)$ & $.518(* *)$ \\
\hline & Sig. (2-tailed) & .000 & .005 & .000 & .000 & .000 & .000 & .000 & .000 & .000 & .000 & .000 \\
\hline & $\mathrm{N}$ & 182 & 182 & 182 & 182 & 161 & 175 & 182 & 182 & 175 & 182 & 182 \\
\hline \multirow[t]{3}{*}{$\begin{array}{l}\text { The school's } \\
\text { unique needs }\end{array}$} & $\begin{array}{l}\text { Pearson } \\
\text { Correlation }\end{array}$ & $.551(* *)$ & $.291(* *)$ & $.474(* *)$ & $.620(* *)$ & $.643(* *)$ & $.692(* *)$ & $.793(* *)$ & $.505(* *)$ & $.644(* *)$ & $.787(* *)$ & $.581(* *)$ \\
\hline & Sig. (2-tailed) & .000 & .000 & .000 & .000 & .000 & .000 & .000 & .000 & .000 & .000 & .000 \\
\hline & $\mathrm{N}$ & 182 & 182 & 182 & 182 & 161 & 175 & 182 & 182 & 175 & 182 & 182 \\
\hline \multirow[t]{3}{*}{$\begin{array}{l}\text { The school's } \\
\text { staffing needs }\end{array}$} & $\begin{array}{l}\text { Pearson } \\
\text { Correlation }\end{array}$ & $.584(* *)$ & $.220(* *)$ & $.513(* *)$ & $.723(* *)$ & $.786\left(^{* *}\right)$ & $.840(* *)$ & $.723(* *)$ & $.631(* *)$ & $.748\left(^{* *}\right)$ & $.603(* *)$ & $.518(* *)$ \\
\hline & Sig. (2-tailed) & .000 & .003 & .000 & .000 & .000 & .000 & .000 & .000 & .000 & .000 & .000 \\
\hline & $\mathrm{N}$ & 182 & 182 & 182 & 182 & 161 & 175 & 182 & 182 & 175 & 182 & 182 \\
\hline
\end{tabular}




\begin{tabular}{|c|c|c|c|c|c|c|c|c|c|c|c|c|}
\hline \multirow{3}{*}{$\begin{array}{l}\text { The laws and } \\
\text { Regulations on } \\
\text { funds allocation }\end{array}$} & $\begin{array}{l}\text { Pearson } \\
\text { Correlation }\end{array}$ & $.573(* *)$ & $.273(* *)$ & $.447(* *)$ & $.564(* *)$ & $.607(* *)$ & $.676(* *)$ & $.782(* *)$ & $.492(* *)$ & $.638\left(^{* *}\right)$ & $.813(* *)$ & $.628(* *)$ \\
\hline & Sig. (2-tailed) & .000 & .000 & .000 & .000 & .000 & .000 & .000 & .000 & .000 & .000 & .000 \\
\hline & $\mathrm{N}$ & 182 & 182 & 182 & 182 & 161 & 175 & 182 & 182 & 175 & 182 & 182 \\
\hline \multirow{3}{*}{$\begin{array}{l}\text { Ministry of } \\
\text { Education goals } \\
\text { and priorities }\end{array}$} & $\begin{array}{l}\text { Pearson } \\
\text { Correlation }\end{array}$ & $.607(* *)$ & $.287(* *)$ & $.401(* *)$ & $.603(* *)$ & $.696(* *)$ & $.745(* *)$ & $.716(* *)$ & $.571(* *)$ & $.635(* *)$ & $.709(* *)$ & $.620(* *)$ \\
\hline & Sig. (2-tailed) & .000 & .000 & .000 & .000 & .000 & .000 & .000 & .000 & .000 & .000 & .000 \\
\hline & $\mathrm{N}$ & 182 & 182 & 182 & 182 & 161 & 175 & 182 & 182 & 175 & 182 & 182 \\
\hline \multirow[t]{3}{*}{$\begin{array}{l}\text { Fairness } \\
\text { equity }\end{array}$} & $\begin{array}{l}\text { Pearson } \\
\text { Correlation }\end{array}$ & $.595(* *)$ & $.213(* *)$ & $.458(* *)$ & $.689(* *)$ & $.742(* *)$ & $.781(* *)$ & $.750(* *)$ & $.588(* *)$ & $.699\left(^{* *}\right)$ & $.714(* *)$ & $.509(* *)$ \\
\hline & Sig. (2-tailed) & .000 & .004 & .000 & .000 & .000 & .000 & .000 & .000 & .000 & .000 & .000 \\
\hline & $\mathrm{N}$ & 182 & 182 & 182 & 182 & 161 & 175 & 182 & 182 & 175 & 182 & 182 \\
\hline \multirow{3}{*}{$\begin{array}{l}\text { Adherence to } \\
\text { the National } \\
\text { Financing } \\
\text { policy }\end{array}$} & $\begin{array}{l}\text { Pearson } \\
\text { Correlation }\end{array}$ & $.357(* *)$ & .099 & $.333(* *)$ & $.340(* *)$ & $.497(* *)$ & $.474(* *)$ & $.612(* *)$ & $.365(* *)$ & $.449^{(* *)}$ & $.674(* *)$ & $.591(* *)$ \\
\hline & Sig. (2-tailed) & .000 & .183 & .000 & .000 & .000 & .000 & .000 & .000 & .000 & .000 & .000 \\
\hline & $\mathrm{N}$ & 182 & 182 & 182 & 182 & 161 & 175 & 182 & 182 & 175 & 182 & 182 \\
\hline
\end{tabular}

** Correlation is significant at the 0.01 level (2-tailed).

High association at $\mathrm{o} \%$ degree of confidence

Moderate association at $\mathrm{o} \%$ degree of confidence

From table 2 in can be observed that the use of the School's strategic plan had high association with provision of latrines / toilets $(0.737$ at 0.000 two tailed significant level), office allocation to departments $(0.719$ at 0.000 two tailed significant level) and availability and reliability of clean water $(0.739$ at 0.000 two tailed significant level) while having a moderate association with furniture / desks in staffroom/ offices ( 0.557 at 0.000 two tailed significant level), science laboratory facilities ( 0.575 at 0.000 two tailed significant level), home science / agriculture rooms facilities ( 0.557 at 0.000 two tailed significant level), dining hall facilities $(0.737$ at 0.000 two tailed significant level), play fields $(0.639$ at 0.000 two tailed significant level) and power availability and reliability ( 0.578 at 0.000 two tailed significant level). Finally, School's strategic plan had low or no association with furniture / desks in the classrooms ( 0.273 at 0.000 two tailed significant level) and library facilities $(0.413$ at 0.000 two tailed significant level).

According to the findings on table 2, departmental budget had high association with provision of science laboratory facilities $(0.716$ at 0.000 two tailed significant level $)$, home science / agriculture rooms facilities $(0.733$ at 0.000 two tailed significant level), latrines / toilets ( 0.777 at 0.000 two tailed significant level), office allocation to departments $(0.853$ at 0.000 two tailed significant level) and availability and reliability of clean water $(0.783$ at 0.000 two tailed significant level) while having a moderate association with furniture / desks in staffroom/ offices ( 0.554 at 0.000 two tailed significant level), library facilities ( 0.530 at 0.000 two tailed significant level), dining hall facilities ( 0.601 at 0.000 two tailed significant level), play fields ( 0.680 at 0.000 two tailed significant level) and power availability and reliability $(0.555$ at 0.000 two tailed significant level). Finally, it had low or no association with furniture / desks in the classrooms (0.208 at 0.000 two tailed significant level) only.

Based on findings of table 2, the School's priorities had low or no association with provision of latrines / toilets $(0.397$ at 0.000 two tailed significant level), office allocation to departments $(0.489$ at 0.000 two tailed significant level), availability and reliability of clean water ( 0.498 at 0.000 two tailed significant level), furniture / desks in staffroom/ offices (0.332 at 0.000 two tailed significant level), science laboratory facilities (0.304 at 0.000 two tailed significant level $)$, home science / agriculture rooms facilities ( 0.214 at 0.000 two tailed significant level), dining hall facilities ( 0.313 at 0.000 two tailed significant level), play fields $(0.465$ at 0.000 two tailed significant level), power availability and reliability (0.348 at 0.000 two tailed significant level), furniture / desks in the classrooms (0.192 at 0.000 two tailed significant level) and library facilities $(0.337$ at 0.000 two tailed significant level).

From table 2 in can be observed that the use of the School's characteristics had high association with provision of office allocation to departments $(0.812$ at 0.000 two tailed significant level) and availability and reliability of clean water ( 0.773 at 0.000 two tailed significant level) while having a moderate association with latrines / toilets ( 0.675 at 0.000 two tailed significant level), library facilities ( 0.503 at 0.000 two tailed significant level), furniture / desks in staffroom/ offices ( 0.513 at 0.000 two tailed significant level), science laboratory facilities ( 0.636 at 0.000 two tailed significant level), home science / agriculture rooms facilities ( 0.619 at 0.000 two tailed significant level), play fields (0.660 at 0.000 two tailed significant level) and power availability and reliability ( 0.629 at 0.000 two tailed significant level). Finally, School's characteristics had low or no association with furniture / desks in the classrooms $(0.283$ at 0.000 two tailed significant level $)$ and dining hall facilities $(0.483$ at 0.000 two tailed significant level).

The school type, according to findings on table 2 had high association with provision of office allocation to departments ( 0.790 at 0.000 two tailed significant level) and availability and reliability of clean water $(0.745$ at 0.000 two tailed significant level) while having a moderate association with latrines / toilets ( 0.685 at 0.000 two tailed significant level), library facilities ( 0.513 at 0.000 two tailed significant level), furniture / desks in staffroom/ offices $(0.634$ at 0.000 two tailed significant level), science laboratory facilities $(0.566$ at 0.000 two tailed significant level), home science / agriculture rooms facilities ( 0.522 at 0.000 two tailed significant level), play fields ( 0.602 at 0.000 two tailed significant level) and power availability and reliability $(0.518$ at 0.000 two tailed 
significant level). Finally, School's characteristics had low or no association with furniture / desks in the classrooms (0.207 at 0.000 two tailed significant level) and dining hall facilities $(0.480$ at 0.000 two tailed significant level).

As per the findings of table 2, the School's unique needs had high association with provision of office allocation to departments ( 0.793 at 0.000 two tailed significant level) and availability and reliability of clean water ( 0.787 at 0.000 two tailed significant level) while having a moderate association with latrines / toilets $(0.692$ at 0.000 two tailed significant level), furniture / desks in staffroom/ offices ( 0.551 at 0.000 two tailed significant level), science laboratory facilities ( 0.620 at 0.000 two tailed significant level), home science / agriculture rooms facilities ( 0.643 at 0.000 two tailed significant level), play fields ( 0.644 at 0.000 two tailed significant level), dining hall facilities ( 0.505 at 0.000 two tailed significant level) and power availability and reliability $(0.581$ at 0.000 two tailed significant level). Finally, School's unique needs had low or no association with furniture / desks in the classrooms ( 0.291 at 0.000 two tailed significant level), and library facilities ( 0.474 at 0.000 two tailed significant level).

From table 2 in can be observed that the use of the School's staffing needs had high association with provision of science laboratory facilities ( 0.723 at 0.000 two tailed significant level), home science / agriculture rooms facilities (0.786 at 0.000 two tailed significant level), latrines / toilets $(0.840$ at 0.000 two tailed significant level), office allocation to departments $(0.723$ at 0.000 two tailed significant level) and play fields $(0.748$ at 0.000 two tailed significant level), while having a moderate association with furniture / desks in staffroom/ offices $(0.584$ at 0.000 two tailed significant level), library facilities ( 0.513 at 0.000 two tailed significant level), dining hall facilities (0.631 at 0.000 two tailed significant level), availability and reliability of clean water $(0.603$ at 0.000 two tailed significant level) and power availability and reliability ( 0.518 at 0.000 two tailed significant level). Finally, it had low or no association with furniture / desks in the classrooms ( 0.220 at 0.000 two tailed significant level).

The laws and regulations on allocation of funds based on findings of table 2 had high association with provision of office allocation to departments (0.782 at 0.000 two tailed significant level) and availability and reliability of clean water $(0.813$ at 0.000 two tailed significant level) while having a moderate association with furniture / desks in staffroom/ offices $(0.573$ at 0.000 two tailed significant level), science laboratory facilities ( 0.564 at 0.000 two tailed significant level), home science / agriculture rooms facilities ( 0.607 at 0.000 two tailed significant level), latrines / toilets ( 0.676 at 0.000 two tailed significant level), play fields ( 0.638 at 0.000 two tailed significant level) and power availability and reliability ( 0.628 at 0.000 two tailed significant level). Finally, they had low or no association with dining hall facilities (0.492 at 0.000 two tailed significant level), furniture / desks in the classrooms (0.273 at 0.000 two tailed significant level) and library facilities $(0.447$ at 0.000 two tailed significant level).

From table 2 in can be observed that the use of the ministry of Education goals and priorities had high association with provision of latrines / toilets $(0.745$ at 0.000 two tailed significant level), office allocation to departments ( 0.716 at 0.000 two tailed significant level) and availability and reliability of clean water $(0.709$ at 0.000 two tailed significant level) while having a moderate association with furniture / desks in staffroom/ offices (0.607 at 0.000 two tailed significant level), science laboratory facilities ( 0.603 at 0.000 two tailed significant level), home science / agriculture rooms facilities ( 0.696 at 0.000 two tailed significant level), dining hall facilities ( 0.571 at 0.000 two tailed significant level), play fields ( 0.635 at 0.000 two tailed significant level) and power availability and reliability ( 0.620 at 0.000 two tailed significant level). Finally, it had low or no association with furniture / desks in the classrooms (0.287 at 0.000 two tailed significant level) and library facilities $(0.401$ at 0.000 two tailed significant level).

Based on findings of table 2, fairness and equity had high association with provision of home science / agriculture rooms facilities ( 0.742 at 0.000 two tailed significant level), latrines / toilets $(0.781$ at 0.000 two tailed significant level), office allocation to departments ( 0.750 at 0.000 two tailed significant level) and availability and reliability of clean water $(0.714$ at 0.000 two tailed significant level) while having a moderate association with furniture / desks in staffroom/ offices ( 0.595 at 0.000 two tailed significant level), science laboratory facilities ( 0.689 at 0.000 two tailed significant level), dining hall facilities ( 0.588 at 0.000 two tailed significant level), play fields ( 0.699 at 0.000 two tailed significant level) and power availability and reliability $(0.509$ at 0.000 two tailed significant level). Finally, it had low or no association with furniture / desks in the classrooms $(0.213$ at 0.000 two tailed significant level) and library facilities ( 0.458 at 0.000 two tailed significant level).

From table 2 in can be observed that adherence to national financing policy had moderate association with provision of office allocation to departments ( 0.612 at 0.000 two tailed significant level), power availability and reliability ( 0.674 at 0.000 two tailed significant level) and availability and reliability of clean water $(0.591$ at 0.000 two tailed significant level). Finally, it had low or no association with furniture / desks in staffroom/ offices $(0.357$ at 0.000 two tailed significant level), furniture / desks in the classrooms (0.099 at 0.000 two tailed significant level), library facilities ( 0.333 at 0.000 two tailed significant level), science laboratory facilities $(0.340$ at 0.000 two tailed significant level), home science / agriculture rooms facilities ( 0.497 at 0.000 two tailed significant level), latrines / toilets $(0.474$ at 0.000 two tailed significant level), dining hall facilities ( 0.365 at 0.000 two tailed significant 
level) and play fields (0.449 at 0.000 two tailed significant level).

From the findings in table 2, it is notable that the school's priorities had no moderate or high association to the provision of any of the physical facilities. Equally, furniture / desks in classrooms had none of the funds allocation determinants having a moderate or high association with it. At the same time adherence to national financing policy had moderate association with provision of only three physical facilities.

The determinants of funds allocation ranked from those having most high and moderate association with provision of physical facilities in the descending order are School's staffing needs, departmental budget, fairness and equity, school's strategic plan, Ministry of Education goals and priorities, the school's characteristics, the school's unique needs, the type of school, the laws and Regulations on funds allocation, adherence to the National Financing policy and finally the school's priorities.

\subsection{Association between perceived funding and adequate provision of physical facilities}

After establishing the relationship between the funds allocation practices and provision of physical facilities provision, the study also sought to understand the association between the perceived funding level and the perceived adequacy of the physical facilities. The findings are as presented in table 3 .

Table 3: Correlation of perceived funding level with adequacy of physical facilities

\begin{tabular}{|c|c|c|}
\hline Facility & & Perceived Funding level \\
\hline \multirow[t]{3}{*}{ Furniture in staffroom / offices } & Pearson Correlation & $.211(* *)$ \\
\hline & Sig. (2-tailed) & .002 \\
\hline & $\mathrm{N}$ & 182 \\
\hline \multirow[t]{3}{*}{ Furniture in the classrooms } & Pearson Correlation & $.203(* *)$ \\
\hline & Sig. (2-tailed) & .003 \\
\hline & $\mathrm{N}$ & 182 \\
\hline \multirow[t]{3}{*}{ Library facilities } & Pearson Correlation & $.494(* *)$ \\
\hline & Sig. (2-tailed) & .000 \\
\hline & $\mathrm{N}$ & 182 \\
\hline \multirow[t]{3}{*}{ Science laboratory facilities } & Pearson Correlation & $.493(* *)$ \\
\hline & Sig. (2-tailed) & .000 \\
\hline & $\mathrm{N}$ & 182 \\
\hline \multirow{3}{*}{ Home science / agriculture rooms facilities } & Pearson Correlation & $.246(* *)$ \\
\hline & Sig. (2-tailed) & .001 \\
\hline & $\mathrm{N}$ & 161 \\
\hline \multirow[t]{3}{*}{ Latrines / Toilets } & Pearson Correlation & $.319(* *)$ \\
\hline & Sig. (2-tailed) & .000 \\
\hline & $\mathrm{N}$ & 175 \\
\hline \multirow[t]{3}{*}{ Offices allocated to departments } & Pearson Correlation & $.491(* *)$ \\
\hline & Sig. (2-tailed) & .000 \\
\hline & $\mathrm{N}$ & 182 \\
\hline \multirow[t]{3}{*}{ Dining hall facilities } & Pearson Correlation & $.239(* *)$ \\
\hline & Sig. (2-tailed) & .001 \\
\hline & $\mathrm{N}$ & 182 \\
\hline \multirow[t]{3}{*}{ Play fields } & Pearson Correlation & $.419(* *)$ \\
\hline & Sig. (2-tailed) & .000 \\
\hline & $\mathrm{N}$ & 175 \\
\hline \multirow[t]{3}{*}{ Availability and reliability of clean water } & Pearson Correlation & $.389(* *)$ \\
\hline & Sig. (2-tailed) & .000 \\
\hline & $\mathrm{N}$ & 182 \\
\hline \multirow[t]{3}{*}{ Power availability and reliability } & Pearson Correlation & $.345(* *)$ \\
\hline & Sig. (2-tailed) & .000 \\
\hline & $\mathrm{N}$ & 182 \\
\hline
\end{tabular}

** Correlation is significant at the 0.01 level (2-tailed).

From findings presented in table 3 , it was found that there was a weak $(0.211$ at 0.002 significance level: two tailed) positive association between perceived funding level and adequate provision of furniture in the staff rooms / offices in public secondary schools in Bungoma county. It was also found that there was a weak (0.203 at 0.003 significance level: two tailed) positive association between perceived funding level and adequate provision of furniture in the class rooms in public secondary schools in Bungoma county. From findings presented in table 3, there was a low ( 0.494 at 0.000 significance level: two tailed) positive association between perceived funding level and adequate provision of library facilities and a low (0.493 at 0.000 significance level: two tailed) positive association between perceived funding level and adequate provision of science laboratory facilities in public 
secondary schools in Bungoma county. It is also observable that there was a weak $(0.246$ at 0.001 significance level: two tailed) positive association between perceived funding level and adequate provision of home science / agriculture rooms facilities in public secondary schools in Bungoma county. An analysis of findings presented in table 3 reveals that there was a weak ( 0.319 at 0.000 significance level: two tailed) positive association between perceived funding level and adequate provision of latrines and toilets in public secondary schools in Bungoma county.

From findings presented in table 3 , it is also observable that there was a weak $(0.491$ at 0.000 significance level: two tailed) positive association between perceived funding level and adequate provision of departmental offices in public secondary schools in Bungoma county. In addition, it is also observable that there was a weak ( 0.239 at 0.001 significance level: two tailed) positive association between perceived funding level and adequate provision of dining hall facilities and a weak ( 0.419 at 0.000 significance level: two tailed) positive association between perceived funding level and adequate provision of play fields in public secondary schools in Bungoma county. From findings presented in table 3 , there was a low ( 0.389 at 0.000 significance level: two tailed) positive association between perceived funding level and adequate provision of clean and reliable water in public secondary schools in Bungoma county. Finally, it is also observable that there was a low (0.345 at 0.000 significance level: two tailed) positive association between perceived funding level and adequate provision of reliable power in Bungoma county public secondary schools.

It is observable that in general, the perceived funding level had either low or hardly any association with adequate provision with all physical facilities. These points to a likelihood of there being a discrepancy between the allocations of funds based on determinants of funds allocation and the actual provision of the physical facilities. This may have arisen from what the bursars explained in interviews that schools hardly stuck the budgets they make as they often vire funds from one vote heads to another.

\subsection{Association between utilisation of physical facilities and learners' academic achievement}

In order to get a clear understanding of the nature of association between perceived funding level for resources and learner's achievement at KCSE, the study employed Pearson's Correlation. The findings are presented in table 5.

Table 5: Correlation between utilisation of physical facilities and learners academic achievement

\begin{tabular}{|lllr|}
\hline & Utilised facility in the teaching learning process & learner's academic achievement \\
\hline 1 & Library facilities & Pearson Correlation & $.548(* *)$ \\
& & Sig. (2-tailed) & .100 \\
& & $\mathrm{~N}$ & 182 \\
\hline \multirow{2}{*}{ Facilities in the science laboratories } & Pearson Correlation & $.754(* *)$ \\
& & Sig. (2-tailed) & .000 \\
& & $\mathrm{~N}$ & 182 \\
\hline 3 & Home science / agriculture room facilities & Pearson Correlation & $.722(* *)$ \\
& & Sig. (2-tailed) & .010 \\
& & $\mathrm{~N}$ & 182 \\
\hline
\end{tabular}

** Correlation is significant at the 0.01 level (2-tailed)

From table 5, it can also be observed that the utilisation of library facilities in public secondary schools in Bungoma county had a strong significant statistical association (0.548 at 0.100 two tailed significant level) with learners academic achievement. The utilisation of facilities in the science laboratories in public secondary schools in Bungoma county had a strong significant statistical association ( 0.754 at 0.000 two tailed significant level) with learners academic achievement. At the same time utilisation of home science / agriculture room facilities in public secondary schools in Bungoma county had a strong significant statistical association (0.722 at 0.010 two tailed significant level) with learners academic achievement.

It is noted that the utilisation of library facilities, facilities in the science laboratories and home science / agriculture room facilities had impact on academic achievement of learners. It is therefore important to ensure utilisation of the physical facilities for teaching learning process in order to influence the learners' academic achievement. According to Okongo, Ngao, Rop and Nyongesa (2015), learning is fruitful when there are adequate physical resources and where they lack; it translates to poor academic performance by learners.

\subsection{Association between perceived funds allocation and learners' academic achievement}

The study further established the nature of association between perceived funds allocation and learner's achievement through the use of Pearson's Correlation. The findings were as presented in table 6. 
Table 6: Correlation between perceived funds allocation and learners achievement

\begin{tabular}{|llr|}
\hline Perceived funds allocation & & learner's academic achievement \\
\hline Allocation funds for resources & Pearson Correlation & .281 \\
& Sig. (2-tailed) & .100 \\
& $\mathrm{~N}$ & 182 \\
\hline
\end{tabular}

** Correlation is significant at the 0.01 level (2-tailed)

From the findings in table 6 , the perceived allocation of funds for resources in public secondary schools in Bungoma county does not have any significant statistical association ( 0.281 at 0.100 two tailed significant level) with learners academic achievement.

However, from table 5, it was noted that the utilisation of physical facilities had significant statistical association with academic achievement of learners. Clearly for physical facilities to be utilised, they must have been procured. And to procure them, funds must have allocated towards them. Therefore, though the allocation of funds does not have a significant relationship to learners' academic achievement, it has an indirect impact on learners' academic achievement.

\subsection{Conclusion}

The well provided for physical facilities included power supply, furniture in the classrooms, furniture in the staffroom and clean water supply while the rest were either moderately or lowly provided for in the order of science laboratories, offices allocated to departments, toilets / latrines, library facilities, play grounds, capacity and equipment for home science /Agriculture and dining hall facilities. According to Conboy (2006) and Okongo et al (2015) physical conditions and organisation of the school can either facilitated or inhibit construction of the culture of success that results in academic achievement by learners. Lack of physical resources would render the schooling experiences ineffective (Bizimana and Orodho, 2014) hence resulting in poor learners academic achievement.

The allocation of funds determinants had high or moderate association on provision of physical facilities in the descending order as follows:- School's staffing needs, departmental budget, fairness and equity, school's strategic plan, Ministry of Education goals and priorities, the school's characteristics, the school's unique needs, the type of school the laws and Regulations on funds allocation and moderate only to a small scale on adherence to the National Financing policy while low or hardly any on the school's priorities.

It was generally observed that the perceived funding level had either low or hardly any association with adequate provision with all physical facilities. It was also established that the utilisation of physical facilities in the teaching learning process had moderate and high association with on academic achievement of learners. Finally, perceived allocation of funds for physical facilities in public secondary schools in Bungoma County hardly had any significant statistical association with learners' academic achievement.

\subsection{Recommendations}

The paper recommends that public secondary schools review the determinants used in funds allocation in order ensure they employ only those that strongly contribute towards provision of adequate physical facilities. They ought also to ensure they stick to the budget to ensure acquisition of the physical facilities and utilize them towards provision of educational services. This is the only way to realise the meaningful learners' academic achievement out of the provision of physical facilities.

\section{References}

Ayoti C., Koteng G. and Odhiambo R. O. (2016) Physical Determinants of Educational Resources Management for Enhancing Students' Performance in Secondary Schools in Vihiga County, Kenya. Research Journal of Education 2(7): 121-128 ISSN(e): 2413-0540, ISSN(p):2413-8886

Bakari J, Likoko S and Ndinyo F (2012) Effects of physical Facilities on Performance in Kenya Certificate of Secondary Examination in Public Schools in Bungoma South, Kenya. International Journal of Science and Research (IJSR) ISSN (Online): 2319-7064

Bijaya N. and Maharjan R. (2015). Effectof School's Physical Facilitieson Learning and Outcomes of Studentsin Nepal. Journal for Studies in Management and Planning. 1 (6):266-279 Available at http://internationaljournalofresearch.org/index.php

Bizimana B. and Orodho J. A. (2014) Teaching and learning resources availability and Teachers' effective classroom management and content delivery in secondary schools in Huye District, Rwanda. Journal of Education and Practice 5(9):111-122

Condron J. D. and Roscigno J. V. (2003) Disparities Within Unequal Spending and Achievement in an Urban School District. American Sociological Association. Sociology of Education 76(1): 18-36

Hailu A. T. and Biyabeyen M. A. (2014). The Availability of School Facilities and Their Effects on the Quality of Education in Government Primary Schools of Harari Regional State and East Hararghe Zone, Ethiopia. 
Middle Eastern \& African Journal of Educational Research 11: 59-71.

Kurgat J. S (2014) Availability and use of Instructional Materials and Facilities towards Enhancing Students performance. Journal of Education and practice 5(33): 116-121

LIPS, Watkins S. and Fleming J. (2008). Does spending more on education improve academic achievement

Livumbaze A. G. and Achoka S.K. J. (2017) Analysing the effects of teaching / learning resources on students' academic achievement in public secondary schools, Hamisi Sub-County, Kenya. European Journal of Education Studies 3(1):361-376 doi:10.5281/zenodo.244169

Lumuli N. C ( 2009) An Investigation into the Internal Efficiency measure in Promotion of Access and Completion Rates in Public Secondary schools in Bungoma South District. Unpublished M.ED Thesis. University of Nairobi.

Lucas, A. M., and Mbiti I. M. (2014). Effects of School Quality on Student Achievement: Discontinuity Evidence from Kenya. American Economic Journal: Applied Economics, 6 (3): 234-63. DOI: 10.1257/app.6.3.234

Mbati P. (2004) FPE Assessment Report. Nairobi, the Jomo Kenyatta

Ministry of Education Science and Technology (2005) Kenya Education Sector Support Programme (2005-2010) Delivering Quality Education and Training to all Kenyans. Nairobi. Government printer

Munda S. W and Odebero S (2014). Influence of Education Cost on Students' Academic Performance in Kenya: An Empirical Study of Bungoma County Secondary Schools. Asian Journal of Educational Research 2(1): $1-11$

Ndiku J. and Muhavi L. (2013) Government Funding On access to Secondary education in Kenya: Challenges and Prospects. Kakamega. Educational Research and Reviews 8(18): 1650-1655.

Okongo R. B., Ngao G., Rop N. K. and Nyongesa W. J. (2015) Effects of availability of teaching and learning resources on the implementation of inclusive education in pre-school centers in Nyamira North Sub-County, Kenya. Journal of Education and Practice 6(35):132-141

Redan, B. W., Marlina, S. R. L. \& Betaubun, M. (2014). Alternative Strategy for Improving The Quality Of Graduates In East Indonesia Border Area (Case Study On State Senior High School Graduates In Merauke Regency). International Journal of Education and Research 2(4), 245-252

Saeed, M., \& Wain, K. U. (2011, December). Status of Missing Physical Facilities in Government Schools of Punjab. Journal of Research and Reflections in Education 5(2): 105-127. Retrieved May 26, 2018, from http://www.ue.edu.pk/jrre

Schneider M. (2002). Do school facilities affect academic outcomes? National Clearing House for educational facilities. Washington D. C. Retrieved from ERIC database (ED470979)

Sherlock M. (2011) The effects of Financial Resources on Test Pass Rate: Evidence from Vermont's Equal Education Opportunity Act. Public Finance Review Sage Journal online 39 (3): 331-364. https://doi.org/10.1177/1091142110396500

Sisungo Z., Kaberia L. and Buhere P. (2014). An investigation on the relationship between the school level of funding and performance at K.C.S.E. in Mumias District, Western Province, Kenya. International Journal of Educational Administration and Policy Studies 6(2): 15-22 https://doi.org/10.5897/IJEAPS11.018

Sunday A. A. (2012). The Relationship among School Environment, Student Approaches to Learning and Their Academic Achievement in Senior Secondary School in Physics. International Journal of Educational Research \& Technology 3(1): 21-26

Wamulla A. J. (2013). Factors influencing academic performance in Kenya certificate of secondary education examinations in private schools in Kenya: Nairobi. University of Nairobi.

Wenglinsky H. (1997) How money matters: The effect of School District Spending on Academic Achievement. American Sociological Association. Sociology of education 70(3): 221-237.

World Bank (2008) National Assessment of Education Achievement Vol.1: Assessing indicators of achievement. Washington D.C.

World Bank (2012) World Bank Working paper No 126: Textbooks and School Library provision in Secondary education in Sub Saharan Africa.

World Bank (2018) Learning to realize education's promise. A World Bank group flagship report. International Bank for Reconstruction and Development The World Bank. ISSN: 0163-5085 ISBN: 978-1-4648-1096-1 eISBN: 978-1-4648-1098-5 DOI: 10.1596/978-1-4648-1096-1 